\title{
Oropharyngeal Cancer pN2 TNM Finding v7
}

National Cancer Institute

\section{Source}

National Cancer Institute. Oropharyngeal Cancer pN2 TNM Finding V7. NCI Thesaurus.

Code C89010.

Oropharyngeal cancer with metastasis in a single ipsilateral lymph node, more than $3 \mathrm{~cm}$ but not more than $6 \mathrm{~cm}$ in greatest dimension, or in multiple ipsilateral lymph nodes,

none more than $6 \mathrm{~cm}$ in greatest dimension, or in bilateral or contralateral lymph nodes, none more than $6 \mathrm{~cm}$ in greatest dimension. (from AJCC 7th Ed.) 